PACS: 95.30.Sf, 98.62.Sb

UDC: $530.122,514.823,523.163$

\title{
The N-point gravitational lens as cover and his the profile cover
}

\author{
S.D. Bronza ${ }^{1}$, A.T. Kotvytskiy ${ }^{2}$, Ye.M. Korostelov ${ }^{3}$ \\ 1 Department of Further Mathematics, Ukrainian State University of Railway Transport, Feuerbach sq 7, 61050 Kharkiv, Ukraine \\ 2 Department of Theoretical Physics, V.N. Karazin Kharkiv National University, Svobody sq. 4, 61022 Kharkiv, Ukraine \\ 3 Department of Researches and Design of Means of Communication, Geodesy and Land Management, \\ Ukrainian State University of Railway Transport, Feuerbach sq 7, 61050 Kharkiv, Ukraine \\ bronza.sem@gmail.com, kotvytskiy@gmail.com,kostya_90_@ukr.net
}

ORCID: 0000-0002-1981-5184

DOI: $10.26565 / 2222-5617-2019-31-07$

The study of mathematical models of gravitational lenses are not direct observations. A special place in such studies is the visualization of the lens model. The image of the source and its images in the N-point gravitational lens, in the picture plane, visualizes the mathematical model - the algebraic equation of the lens. Recently, the number of studies of the equation of the N-point gravitational lens by algebraic methods has increased [6-8]. Such studies make it possible to consider the gravitational lens not only as an algebraic, but also as a topological object.

In the work, the equation of the N-point gravitational lens in the complex form is studied. A bundle above the source plane is assigned to it. We investigated one subfamily of lens equations. A critical set of equations of this subfamily is a closed Jordan curve. To the equations of this subfamily we put in correspondence not only a vector bundle, but also a covering.

A method for describing coverings is developed for equations whose caustic in the finite plane is a closed Jordan curve (Jordan caustic). A special case of such coverings is coverings for the equation of an $\mathrm{N}$-point gravitational lens, the critical set of which is a closed Jordan curve. These equations, also, have Jordan caustics. The method is similar to the method for describing Riemann surfaces of algebraic functions, graphs - profiles.

The algorithm for constructing coverings and the developed method for describing these coverings illustrates an example of a cover given by a rational non-analytic function of a complex variable The covering surface has not only a Jordan caustic, but also a second-order branch point at an infinitely distant point.

The methods of the theory of functions of a complex variable, algebraic geometry, algebraic topology and graph theory are used.

Keywords: gravitational lens, lens equation, critical curve, caustic, covering map, covering profile.

\section{N-точкова гравітаційна лінза як накриття і іï профіль накриття}

\section{С.Д. Бронза ${ }^{1}$, А.Т. Котвицький ${ }^{2}$, Є.М. Коростельов ${ }^{3}$}

1 Кафедра вищої математики, Украйнський державний університет залізничного транспорту, пл. Фейєрбаха, 7, Харків 61050, Украӥна 2 Харківський національний університет імені В.Н. Каразіна, м. Свободи 4, 61022, Харків, Україна

3 Кафедра Вишукувань та проектування иляхів сполучення, геодезії та землеустрою, Украӥнський державний університет залізничного транспорту, пл. Фейєрбаха, 7, Харків 61050, Украӥна

Дослідження математичних моделей гравітаційних лінз відносяться до не прямих спостережень. Особливе місце в таких дослідженнях займає візуалізація моделі лінзи. Зображення джерела і його зображень в N-точкової гравітаційної лінзи, в картинній площині, візуалізує математичну модель - алгебраїчне рівняння лінзи. Останнім часом збільшилася кількість досліджень рівняння N-точкової гравітаційної лінзи алгебраїчними методами [6-8]. Такі дослідження дають можливість розглядати гравітаційну лінзу не тільки як алгебраїчний, але і як топологічний об'єкт.

В роботі досліджено рівняння $\mathrm{N}$-точкової гравітаційної лінзи в комплексному вигляді. Йому поставлено у відповідність розшарування над площиною джерела. Ми досліджували одну підродину лінзових рівнянь.

Критична множина рівнянь цієї підродини є замкнутою жордановою кривою. Рівнянням цієї підродини ми поставили у відповідність не тільки векторне розшарування, а й накриття. Розроблено метод опису накриттів, для рівнянь, каустика яких в кінцевій площині є замкнутою жордановою кривою (жорданова каустика). Окремим випадком таких накриттів $є$ накриття для рівняння N-точкової гравітаційної лінзи, критична множина якого є замкнута жорданова крива. Ці рівняння, також, мають жорданову каустику. Метод $є$ подібний до методу опису ріманових поверхонь алгебраїчних функцій, графами - профілями.

Алгоритм побудови накриттів і розроблений метод опису цих накриттів ілюструє приклад накриття, яке задано раціональною не аналітичною функцією комплексного змінного. Накриваюча поверхня має не тільки жорданову каустику, а й точку розгалуження другого порядку в нескінченно віддаленій точці.

У роботі використані методи теорії функцій комплексного змінного, алгебраїчної геометрії, алгебраїчної топології та теорії графів.

Ключові слова: гравітаційна лінза, рівняння лінзи, критична крива, каустика, накриття, профіль накриття 


\title{
N-точечная гравитационная линза как накрытие и её профиль
}

\section{накрытия}

\author{
С.Д. Бронза ${ }^{1}$, А.Т. Котвицкий ${ }^{2}$, Е.М. Коростелев ${ }^{3}$ \\ 1 Кафедра высшей математики, Украинский государственный университет железнодорожного транспорта, Фейербаха пл., 7, г. Харьков \\ 61050, Украина \\ 2 Харьковский национальный университет имени В.Н. Каразина, м. Свободы 4, 61022, Харьков, Украина \\ 3 Кафедра изысканий и проектирования путей сообщения, геодезии и землеустройства, Украинский государственньй университет \\ железнодорожного транспорта, Фейербаха пл., 7, г. Харьков 61050, Украина
}

Исследование математических моделей гравитационных линз относятся к не прямым наблюдениям. Особое место в таких исследованиях занимает визуализация модели линзы. Изображение источника и его изображений в $\mathrm{N}$-точечной гравитационной линзе, в картинной плоскости, визуализирует математическую модель - алгебраическое уравнение линзы. В последнее время увеличилось число исследований уравнения $\mathrm{N}$-точечной гравитационной линзы алгебраическими методами [6-8]. Такие исследования дают возможность рассматривать гравитационную линзу не только как алгебраический, но и как топологический объект.

В работе исследовано уравнение N-точечной гравитационной линзы в комплексном виде. Ему поставлено в соответствие расслоение над плоскостью источника. Мы исследовали одно подсемейство линзовых уравнений. Критическое множество уравнений этого подсемейства является замкнутой жордановой кривой. Уравнениям этого подсемейства мы поставили в соответствие не только векторное расслоение, но и накрытие. Разработан метод описания накрытий, для уравнений, каустика которых в конечной плоскости является замкнутой жордановой кривой (жорданова каустика). Частным случаем таких накрытий являются накрытия для уравнения $\mathrm{N}$-точечной гравитационной линзы, критическое множество которого есть замкнутая жорданова кривая. Эти уравнения, также, имеют жорданову каустику. Метод подобен методу описания римановых поверхностей алгебраических функций, графами - профилями.

Алгоритм построения накрытий и разработанный метод описания этих накрытий иллюстрирует пример накрытия, которое задано рациональной не аналитической функцией комплексного переменного. Накрывающая поверхность имеет не только жорданову каустику, но и точку ветвления второго порядка в бесконечно удаленной точке.

В работе использованы методы теории функций комплексного переменного, алгебраической геометрии, алгебраической топологии и теории графов.

Ключевые слова: гравитационная линза, уравнение линзы, критическая кривая, каустика, накрытие, профиль накрытия.

\section{Introduction}

In this paper, the plano N-point gravitational lens [1] is specified by the equation in a complex form and is studied as a vector bundle over the source plane.

We considered the N-point gravitational lens as a bundle above the source plane. Among other things, one subfamily of lens equations has been studied. Equations from this family are assigned not only to the vector bundle, but also to the covering map. For such equations, a method of describing covering maps has been developed.

The developed method is similar to the method of describing Riemann surfaces of algebraic functions by profiles.

\section{Lens mapping and the equation that specifies it}

The plano N-point gravitational lens determines an unequivocal complex mapping

$$
L:\left(C_{z} \backslash A\right) \rightarrow C_{\zeta}
$$

from the complex plane $C_{z}$ - the lens plane to the complex plane $C_{\zeta}$ - the source plane, where $c$ is the set of complex numbers $A=\left\{A_{n} \mid A_{n}=a_{n}+b_{n} i, n=1, \ldots, N\right\}$.
The mapping (1) is specified by the complex equation

$$
\zeta=z-\overline{w(z)}
$$

wherein

$$
w=\sum_{n=1}^{N} m_{n} \frac{1}{\left(z-A_{n}\right)} ; \sum_{n=1}^{N} m_{n}=1
$$

where $m_{n}$ are normalized point masses of the lens, $A_{n}$ are their complex coordinates [9]. Function, $z-\overline{w(z)}$ is rational, but not analytical.

Denote a set of the form (2) by $\zeta_{N}$ and call it a set of N-point gravitational lens equations.

The mapping (1) can be extended to unequivocal complex map by continuity

$$
L:\left(\bar{C}_{z}\right) \rightarrow \bar{C}_{\zeta}
$$

Note that the mapping (4) is continuous in the entire extended complex plane $\bar{C}_{z}$. Mapping $L^{-1}$ inverse to the mapping (4): 


$$
L^{-1}:\left(\bar{C}_{\zeta}\right) \rightarrow \bar{C}_{z}
$$

is obviously multivalued.

Consider next a wider family of equations (3). Let $\mathfrak{R}=\{R(z, \bar{z})\}$ be a set of rational functions $\zeta=R(z, \bar{z})$ from variables $z$ and $\bar{z}$. Obviously, the inclusion of $\zeta_{N} \subset \mathfrak{R}$ holds. The following theorem holds.

Theorem 1. Let the function $f \in \mathfrak{R}$. The function $f \in \zeta_{N}$ if and only if the function $f$ is conceived of as $f=z-\overline{r(z)}$, where $r(z)=\frac{a(z)}{b(z)}$ rational function $z$, degree $\operatorname{deg} a(z)=N-1$ and degree $\operatorname{deg} b(z)=N$ of polynomials $a(z)$ and $b(z)$ have leading zero coefficients, the rational function $r(z)$ has $N$ simple poles at the points $A_{n}, n=1, \ldots, N$, with residues $\underset{A_{n}}{\operatorname{res}} r(z)$ $: 0<\underset{A_{n}}{\operatorname{res} r}(z)<1$ and $\sum_{n=1}^{N} \underset{A_{n}}{\operatorname{res} r}(z)=1$.

Remark 1. The set $\mathfrak{R}$ is the set of rational, in general, not analytical functions. The set $\mathfrak{R}$ includes as a subset the set of rational analytical functions. These are functions of the form $R=R(z)$.

\section{Solution and critical set of the $\zeta=R(z, \bar{z})$ equation}

Let $R=R(z, \bar{z}) \in \mathfrak{R}$. Let make some remarks about the solution of the equation

$$
\zeta=R(z, \bar{z})
$$

Equation (7) is equivalent to a system of equations:

$$
\left\{\begin{array}{l}
\zeta=R(z, \bar{z}) \\
\bar{\zeta}=\bar{R}(z, \bar{z})
\end{array} .\right.
$$

Equation (8) is equivalent to a system of polynomial equations:

$$
\left\{\begin{array}{l}
F(z, \bar{z}, \zeta)=0 \\
\bar{F}(z, \bar{z}, \bar{\zeta})=0
\end{array}\right.
$$

The system of equations (9) and therefore (8) can have one-dimensional zero-dimensional - point solutions, see [6]. There are algorithms that make it possible to determine a set of zero-dimensional solutions and a set of one-dimensional solutions [6]. Equation (7) and the systems of equations (8) and (9) have no one-dimensional solutions, if none of the resultant $R_{z}(F(z, \bar{z}, \zeta), \bar{F}(z, \bar{z}, \bar{\zeta}))$ and $R_{\bar{z}}(F(z, \bar{z}, \zeta), \bar{F}(z, \bar{z}, \bar{\zeta}))$ is identically zero. It is known that the family of equations $\zeta_{N}$ has a single onedimensional solution - the Einstein ring.

Based on this, in considering the $\mathfrak{R}$ family, we can restrict ourselves to functions that do not have onedimensional solutions.

Let the mapping (4) be specified by equation (7), then following theorem holds.

Theorem 2. Let $J$ be the Jacobian of the transformation (8), then the critical mapping set (4) is the set of solutions of the equation $\left|\zeta_{z}^{\prime}\right|-\left|\zeta_{\bar{z}}^{\prime}\right|=0$, for the equations of the gravitational lens - the equations $\left|w_{z}^{\prime}\right|=1$ , and for the analytical - the equations $\zeta_{z}^{\prime}=0$.

Remark 2. The set of solutions of the equation $\zeta_{z}^{\prime}=0$ is a discrete finite set.

\section{Bundles and covering maps}

Definition. Let $M$ and $N$ be topological spaces, and $f$ a continuous mapping of the first to the second, that is $f: M \rightarrow N$. A triple of the form $(M, f, N)$ is called a bundle and denoted by $\Omega$. The topological space $M$ is called the total bundle space and is denoted by $t l \Omega$, the topological space $N$ is the base of the bundle and is denoted by $b s \Omega$, and the $f$ map by the design map and denoted by $\operatorname{pr} \Omega$.

Definition. The layer, of the bundle AA over point $\mathrm{P}$ is called its inverse image of PP.

The regular point of a bundle of $\Omega$ is called a point $b \in t l \Omega$ if it has a neighborhood of $U$ such that the reduction of the map of the $p r \xi$ onto it is a homeomorphism onto the projection of $\operatorname{pr} \xi(U)$. An irregular point FF is called a singular bundle point $t l \Omega$.

Definition. The bundle $\Omega=(M, f, N)$, with a discrete layer at each point, is called a covering if the thickness of all layers is the same. The thickness of the layer is called the number of sheets. The cover may have a finite or countable number of sheets. If the number of sheets is finite and equal to $n$, then by covering we mean the four $(M, f, N, n)$. 
Remark 3. A mapping of the form (4) can be associated with a triple $\Omega=\left(\left(\bar{C}_{\xi} \backslash \Theta\right), L,\left(\bar{C}_{z} \backslash L(\Theta)\right)\right)$, where $\Theta$ is the set of solutions of the equation $J=0$ (critical set). This triple is two-dimensional bundles over the complex plane; see [2].

Remark 4. Let the mapping (4) be given by the equation $\zeta=R(z)$, where $R(z)$ is a rational analytic function and $n=\operatorname{deg} R(z)$, Then (4) we can associate the covering $\Omega=\left((M \backslash \Theta), L,\left(\bar{C}_{z} \backslash L(\Theta)\right), n\right)$, where $M$ is the Riemann surface of an algebraic function that is inverse to the rational function $R(z)$.

\section{Construction coverings}

The covering for an algebraic function can be defined by a graph of a special form - a profile of a Riemann surface, for more details see [4], or a complex of segments, see [5].

We consider another case where the vector bundle can be defined as a cover, and the cover is described by a graph similar to the profile of a Riemann surface.

Let the vector bundle $\Omega$ be defined by equation (7). Let, in addition, the critical set of equation (7) is a closed Jordan curve. Then the one-dimensional vector bundle over the caustic can be defined before covering. Such coverings will be called simple.

Let $J=J(L)$ is the Jacobean of the map $L, \Theta$ is the set of solutions of the $J=0$ equation (critical set), $K=L(\Theta)$ is the caustic, and $Q=L^{-1}(K)=L^{-1}(L(\Theta))$ is the image of the caustic for the inverse map (full inverse image). Let hereditary topologies be given on the sets $K$ and $Q$, and let $F$ be the restriction of the map $L$ to $Q$. Then $\varsigma=(Q, F, K)$ is a one-dimensional bundle. For any regular point $p \in K$, the thickness of the $n=p r \xi^{-1}(p)$ layer has the evenness of the number of $N$ and the number of $n$ satisfies the $N+1<n<N^{2}+1$ inequality. If the critical set is a closed Jordan curve, then the caustic is also a closed Jordan curve. In this case, the thickness of the layer is the same at all regular points, and the onedimensional bundle can be defined before covering.

Thus, in the above terms, the following theorem holds.

Theorem 3. A set of four $\xi=\left(p r \xi^{-1}(K), f, K, n\right)$ elements, where $f$ is the restriction of the map of $F$ to $\operatorname{pr} \xi^{-1}(K)$, is an $n$-branched covering. Cover $\xi$ is a simple cover.

A simple cover uniquely defines a gravitational lens.
Example 1. The complex mapping of $L: C_{z} \rightarrow C_{\zeta}$ is given by the $\zeta=z^{2}+2 \cdot \bar{z}$ equation. Build a caustic, its full prototype and cover.

Decision: Jacobean: $J=4|z|^{2}-4$. The critical set is a circle of $|z|=1$. The equation of caustics $\zeta=e^{2 \varphi i}+2 e^{-\varphi i}, \varphi \in[0,2 \pi)$ is a hypocycloid. Equation of the full prototype of caustics is $e^{2 \varphi i}+2 e^{-\varphi i}=z^{2}+2 \cdot \bar{z}, \varphi \in[0,2 \pi]$.

The graphs of the caustic and its full prototype are shown in Fig. 1.

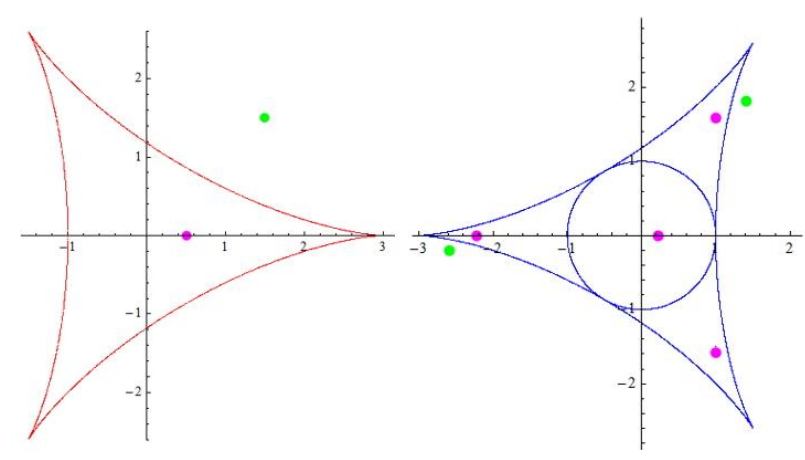

Fig. 1. Caustic graph (left). Graph of the full prototype (right). Gray dots are point sources and their images. A source located outside the caustic (light dot) has two images. The source inside the caustic (dark dot) has four images.

We construct a covering of $\xi=(M, f, N, n)$ over the caustic. The set of solutions of the $e^{2 \varphi i}+2 e^{-\varphi i}=z^{2}+2 \cdot \bar{z}, \varphi \in[0,2 \pi]$ equation determines the covering space $M$. The set of solutions of the $\zeta=e^{2 \varphi i}+2 e^{-\varphi i}, \varphi \in[0,2 \pi)$ equation determines the basis for covering the $N$. Design mapping $f: \zeta=z^{2}+2 \cdot \bar{z}$. The number of sheets is $n=4$.

\section{Description of coverings by graphs}

The simple one-dimensional covering of $\xi=\left(p r \xi^{-1}(K), f, K, n\right)$, from Theorem 3, can be described by a graph - the covering profile.

We give the necessary definitions.

Definition. Let $G_{q}$ be a flat contour with $q$ vertices $a_{j}, j=1,2, \ldots, q$, and $\mathrm{K}_{q}=G_{q} \bigcup_{j=1}^{q} \pi_{j}$ is its union with $q$ oriented loops of $\pi_{j}$ (one loop at each vertex). Let $\pi_{j}$ contour and $\pi_{j}$ loops have a positive orientation (faces 
with positive traversal remain on the left). Let the $\pi_{j}$ loops be located outside the face of the $G_{q}$ graph.

We will call the $F=\mathrm{K}_{q}$ graph a wreath from $q$ circles, and the $G_{q}$ contour - the main contour of the wreath. The arcs of the main contour will be called strong arcs, and loops weak arcs.

Definition. Let $\mathrm{K}_{q}$ be a wreath from $q$ circles. By the $\Pi$ profile of the thickness of the $n$ and the length $q$, we mean an $n$-sheet unbranched covering $\eta=\left(\Pi, \pi, \mathrm{K}_{q}, n\right)$, if the restriction of the mapping of $\pi$ onto the main contour of the wreath is a trivial covering.

The image of the total $t l \eta=\Pi$ space, when displaying $\operatorname{pr} \eta=\pi$, is a wreath $\mathrm{K}_{q}$.

This image can be considered as a directed graph.

The orientation of the arcs in the $\Pi$ graph is induced by the orientation of the wreath arcs.

In the graph of $\Pi$ we will distinguish two types of arcs.

Strong arcs are prototypes of arcs of the main contour. Weak arcs are prototypes of loops.

We point out some properties of the profile. Strong arcs form $n$ of disjoint (strong) contours, $q$ arcs in each. Weak arcs are connected only vertices from one layer. Each vertex includes two arcs: one strong and one weak. Two arcs emanate from each vertex: one strong and one weak.

The profile has an accurate coverage of $n$ by alternating contours of the $2 q$ length, see [4].

We accept the agreement on the profile image.

We will depict a profile:

- in layers (vertices from one layer are projected into your image);

- by sheets (strong contours are depicted as $n$ parallel segments);

- ends of parallel segments are identified.

Fig. 4 shows a profile of length 4 and thickness 3 , the image of the basis loops are omitted.

\section{The Building profiles}

We construct the profile of the covering $\xi=\left(p r \xi^{-1}(K), f, K, n\right)$ over the caustic $K$.

We set a positive orientation on $K$.We associate the caustic $K$ and its complete inverse image $M=p r \xi^{-1}(K)$ with the flat graphs $\operatorname{gr} K$ and $\operatorname{gr} M$, respectively. The mapping associating is denoted by $g r$. Let caustic $K$ have $q$ caps. We assign the caps of the caustics and their images to the vertices of the graphs. We assign the arcs of the graphs to the caustic arcs of their images.

The arcs of the graphs $g r K$ and $g r M$ are defined as strong. Incidence in columns is defined as hereditary.The graph $g r K$ has two faces. We will call the inner face of the graph $g r K$ that face whose boundary is positively oriented. Another facet will be called external.

We define in $g r M$ the external and internal faces.

We put in correspondence with the graph $g r K \mathrm{r}$ the wreath $\mathrm{K}_{q}$. We supplement $g r K$ at the vertices with loops that lie in the outer fase of the caustic. We set the loops to positive orientation.

We supplement the graph $g r M$ with weak arcs. The inner faces of the graph $g r M$ and their boundaries (strong contours) are left unchanged. We add weak arcs to the boundary of each outer face of the $g r M$ graph so that the boundary becomes an alternating contour of length $2 q$.

The resulting graph is denoted by $M_{q}$. Let the mapping

$$
f_{q}: f_{q}=g r \cdot f \cdot(g r)^{-1}
$$

Then $\eta=\left(M_{q}, f_{q}, \mathrm{~K}_{q}, n\right)$, by construction, is a covering, and this covering is a profile.

Example 2. The cover over the caustic of Example 1 can be associated with the profile of the one-dimensional cover, which is shown in Fig. 3. The construction of the profile is illustrated in Fig. 2. Profile in Fig. 3. is depicted by sheets and in layers.
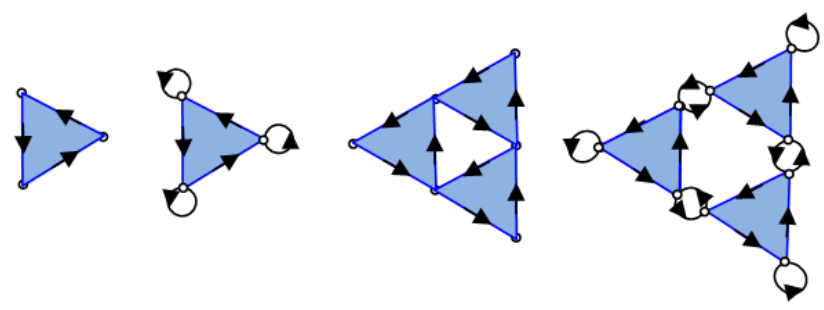

Fig. 2. From left to right, Count $g r K$, Wreath $\mathrm{K}_{q}$, Count grM and Count $M_{a}$. The inner edges are gray.

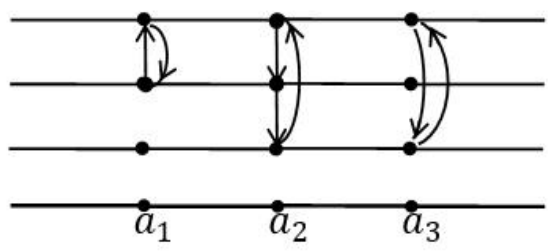

Fig. 3. The cover over the caustic of Example 1 can be associated with the profile of the one-dimensional cover, which is shown in figure. 


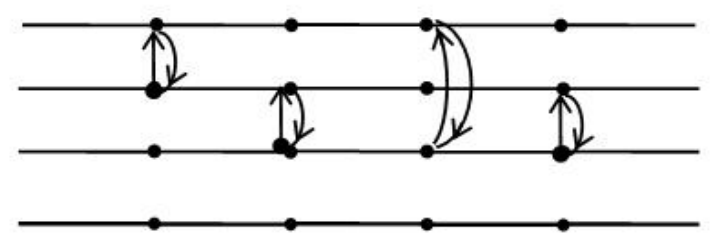

Fig. 4. The profile of length 4 and thickness 3 , the image of the basis loops are omitted.

The two-dimensional covering, from Example 1, obviously, has a branch point of the first order at the point $\zeta=\infty$. The profile of this cover is shown in Fig. 4. The cover profile, in Fig. 4 has a precise coating with alternating contours.

\section{References}

1. P. Schneider, J. Ehlers, E.E. Falco. Gravitational lenses, Springer-Verlag, Berlin Heidelberg (1999), p. 560.

2. V.A. Rokhlin, D.B. Fuks. Nachal’ny`j kurs topologii. Geometricheskie glavy`, Nauka, M. (1977), 488 s.

3. R. Nevanlinna. Verhandl. Internat. Mathematiker-Kongr., Zurich, (1932), p. 221.

4. S.D. Bronza, V.G. Tairova. Teoriya funkczij, funk. analiz i ikh prilozheniya, 33, 12 (1980).

5. R. Nevanlinna, Odnoznachnye analitichtskie funkcii, GITTL, M. - L. (1941), 338 p. (in Russian)

6. S.D. Bronza, A.T. Kotvytskiy. Bulletin of V.N. Karazin Kharkiv National University (Physics), 26, 1120, 6 (2017).

7. K. Danek, D. Heyrovsky. The Astrophysical Journal, 806, 63 (2015).

8. H.J. Witt. A\&A, 236, 2, 311 (1990).

9. A.T. Kotvytskiy, V.Yu. Shablenko, E.S. Bronza. Odessa Astron. Publ., 31, 24 (2018). 